УДК 947

DOI: $10.17223 / 19988613 / 55 / 8$

\title{
А.В. Сушко
}

\section{К ОЦЕНКАМ РЕВОЛЮЦИИ В РОССИИ В МАСШТАБАХ МИРОВОЙ И НАЦИОНАЛЬНОЙ ИСТОРИЙ}

\author{
Публикация подготовлена в рамках поддержанного РФФИ научного проекта № 16-03-00421.
}

\begin{abstract}
Статья посвящена оценкам значения революции в России в масштабах мировой и национальной историй в течение XX - начала XXI в. Поддерживается точка зрения о наличии единой Русской революции, в ходе развития которой были Февраль и Октябрь как ее важнейшие этапы. Победившие в ходе революции в России большевики предложили человечеству идею, позволившую Русской революции заслуженно получить статус «Великой» революции в мировой истории. Это была идея «социальной справедливости». В то же время Русская революция, не выработав национальной идеи, для русского народа стала катастрофой. Автор приходит к выводу, что в современных условиях социалистическая идея имеет политическую перспективу в случае ее сочетания с национальной идеей, способной активизировать созидательный потенциал русского народа.

Ключевые слова: революция в России; Русская революция; Февральская революция; Октябрьская революция, социализм.
\end{abstract}

Революцию в России историки традиционно называют «Великой». При этом на протяжении ХХ столетия толкование величия революции изменялось. В марте 1917 г. русская либеральная и социалистическая интеллигенция в большинстве с восторгом встретила отречение императора Николая II от престола. Исследовавший эмоциональную атмосферу Февраля В.Б. Аксенов отмечает, что «радостно принявшие революцию современники назвали ее первые недели “медовым месяцем", развивая тем самым аллегорию России-невесты, обвенчавшейся со свободой. Другие окрестили февральские дни “великой бескровной революцией”» [1. С. 19]. После победы Октябрьского вооруженного восстания в Петрограде и утверждения в результате кровавой Гражданской войны у власти большевиков свет Февраля померк, и «Великим» стал Октябрь. В советской историографии за ним закрепилось официальное название «Великая Октябрьская социалистическая революция». Крах коммунистической партии и распад СССР в общем не поколебали оценки величия революции в России в профессиональном сообществе современных отечественных историков. Однако оценки этого величия стали разными. Историки-либералы стали говорить о величии Февраля, историки социалистических взглядов продолжают писать о Великом Октябре, большинство же отечественных историков стали говорить об одной Великой Русской / Российской революции и, соответственно, ее февральском и октябрьском этапах. Подтверждением сказанному служат материалы круглого стола «Революция 1917 года в России: причины и предпосылки», состоявшегося 1 марта 2017 г. в Новосибирске. Его соорганизаторами были Институт истории Сибирского отделения РАН и Новосибирский государственный университет. Ведущие сибирские историки дали однозначный утвердительный ответ на поставленный вопрос. Директор Сибирского института управления РАНХиГС С.Р. Сверчков, председатель отделения
Российского исторического общества в Новосибирске, заявил, что «Великая Российская революция - главное событие XX века для нашей страны и для всего мира». Заведующий сектором ИИ СО РАН, профессор НГУ В.И. Шишкин подчеркнул, что «Февральская революция 1917 года - это выдающееся событие, это событие не только российской, но и мировой истории, это великая революция, это народная революция» [2].

В пользу понимания единства революции в России, где в 1917 г. было не две, а одна революция, приведем два аргумента. Во-первых, признание единства революции соответствует смысловому содержанию понятия «революция», отражающему масштабный процессуальный характер события, имеющего внутренние этапы развития. Германские исследователи, стоявшие у истоков научного направления «история понятий», проанализировав появление и содержание понятия «революция», пишут: «Новое понятие обладало способностью поднимать “беспорядки”, “войну”, “гражданскую войну” над уровнем чисто теологического, чисто юридического или чисто политического толкования и помещать их в контекст большой временной протяженности». При этом они подчеркивают, что «только с появлением слова “революция” в его “физико-политическом значении” было найдено такое понятие, которое демонстрировало необходимость самих этапов протекания процесса» [3. С. 616-617]. Во-вторых, точка зрения об одной революции в России (революционном процессе, составными частями которого являются Февраль и Октябрь) исключает возможность считать Февраль или Октябрь (в зависимости от политических предпочтений) «плохой революцией» - ошибкой исторического развития.

В этой связи важно, что современники разных убеждений, пережившие революцию, в основном не разделяли Февраль и Октябрь. Один из главных творцов Октября Л.Д. Троцкий настаивал на том, что «Февральская 
революция была только оболочкой, в которой скрывалось ядро Октябрьской революции» [4. С. 24]. Его идеологический оппонент, известный русский эмигрантский историк А.А. Керсновский утверждал, что «русская революция представляет одно и нераздельное и неразрывное целое». Историк, справедливо критикуя точку зрения о «хорошем» Феврале и «плохом» Октябре, возлагал вину за трагедию русского народа в первую очередь на политиков Февраля, не снимая ответственности за историческую драму русского народа и с Октября. Он писал: «Вина Ленина, зря погубившего тридцать миллионов русских жизней, огромна. Но еще больше ответственность Керенского, давшего возможность Ленину погубить эти тридцать миллионов жизней. Это самая страшная ответственность, какую знает История...» [5. С. 327-328]. В большинстве своем современные российские историки также поддерживают точку зрения о едином революционном процессе в России. Например, С.В. Тютюкин на круглом столе, посвященном 90-летию революции в России, состоявшемся в Институте российской истории РАН, говорил: «Революционные события 1917 г. и ряда последующих лет включают в себя: свержение царизма и провозглашение России демократической республикой, установление и упрочнение советской власти и Гражданскую войну, закрепившую победу большевиков, действовавших от имени рабочих и беднейших крестьян. Таким образом, мы можем говорить о Великой российской революции 1917-1921 гг. - великой по своим масштабам, глубине произошедших в ее результате социально-политических трансформаций, последствий и всемирному значению» [6. С. 171].

В современных условиях для России актуально внутреннее самопознание Русской революции в интересах настоящего и будущего общественно-политического развития страны. В декабре 2016 г. Президент России В.В. Путин в послании к Федеральному Собранию об этом сказал следующее: «Наступающий, 2017 год - год столетия Февральской и Октябрьской революций. Это весомый повод еще раз обратиться к причинам и самой природе революций в России. Не только для историков, ученых - российское общество нуждается в объективном, честном, глубоком анализе этих событий» [7]. Принимая во внимание неоднократно менявшиеся в отечественной историографии и историческом сознании россиян оценки революционных событий в России, в год столетия Русской революции правомерно поставить вопрос об основаниях, дающих право утверждать о величии Русской революции в мировой и отечественной истории.

Если оценивать Русскую революцию в масштабах мировой истории, то ее величие, обусловленное влиянием революционных событий на развитие человечества, не вызывает сомнений. Современные историки связывают Русскую революцию с развитием ситуации в мире - с вызовом модерна, исходившего от Запада. В.Б. Шепелева пишет: «Для России к 1917 г. обозначилась крайне сложная ситуация: жесткий вызов эпохи модернизации совместился с развертыванием в мире “эпохи осознанной необходимости” - ее требований. И Первая мировая война заставила ведущие страны-участницы действовать в рамках нового алгоритма - “осознанной необходимости” - посредством системы ГМК. Уточним: монополистический капитализм уже фактически, по необходимости, есть вступление в “эпоху осознанной необходимости”. На гносеологическом уровне марксизм, по определению Зб. Бжезинского, кладет конец “эпохе исторической бессознательности”. А в России А.И. Герцен впервые в мире формулирует идею выбора пути исторического развития - сущностную идею “эпохи осознанной необходимости”, идею, как бы из недр сегодняшней постнеклассики» [8. С. 38]. М.А. Фельдман подчеркивает связь Октября с глобальными процессами. Он отмечает, что «понимание Октябрьской революции как части мирового процесса социального освобождения выводит и на признание того, что весь советский проект - составная часть подобных трансформаций не только в научной, технологической, технической, военно-технической, но и в социальной сфере в широком понимании этого термина» [9. С. 172].

По влиянию на мир в ХХ в. революционные события в России уступают только двум мировым войнам. Победившие в ходе революции в России большевики предложили человечеству идею, позволившую Русской революции заслуженно получить статус «Великой» революции в мировой истории. Это была идея «социальной справедливости». В результате победы социалистической революции в России большая часть истории XX в. определялась борьбой российской цивилизации (в образе СССР), начертавшей на своих знаменах идею «социальной справедливости», с либеральным капиталистическим Западом. Об этом выдающийся британский историк Арнольд Тойнби писал: «С момента коммунистической революции, последовавшей за либеральной революцией 1917 г., Россия бросила вызов Западу, какого он не знал со времен второй оттоманской осады Вены в 1683 г. Коммунистический российский вызов Западу был не только вызовом господству Запада над всем остальным миром; это был также вызов западному либерализму от имени западной идеологии, которая теперь стала действенной силой в великой незападной стране. Под предводительством России коммунизм вознамерился соревноваться с либерализмом за умы и сердца незападного большинства человечества, которые еще не предались ни одному из двух этих соперничающих жизненных путей. Российский коммунизм также бросил вызов либерализму на его родной земле, в западных странах» [10. С. 220]. Долгое время исход этой борьбы был не ясен. Но поражение СССР в холодной войне в значительной мере обесценило значение Русской революции в мировой истории, серьезно ударив по популярности социалистической идеи во всем мире.

Если оценивать революцию в России в масштабах национальной истории русского народа, то ее величие 
не представляется бесспорным. Здесь уместно сравнить революции во Франции и в России с точки зрения значимости для национальной истории. Предшествовавшая Русской революции Великая Французская революция прочно закрепила за собой статус «Великой» за счет утверждения «идеи нации». Она стала именно Великой Франщузской революцией, породившей нацию французов, представители которой сегодня с величайшим уважением и гордостью относятся к этому ключевому событию своей истории. В честь Великой Французской революции установлен государственный праздник - День взятия Бастилии, отмечающийся военным парадом в Париже и фейерверками по всей стране. В результате революции французы сакрализировали французскую нацию. Американская исследовательница Лия Гринфилд об этом пишет: «Она была не просто нацией - она была Великой Нацией, La Grande Nation, самой национальной из всех наций, доводившей до совершенства все добродетели, которых требовал новый культ» [11. С. 184]. Породив современную французскую нацию, революция стала национальной «Французской» и «Великой» для французского народа. Французская революция стала «Великой» и для остального человечества, сделав национальную идею сакральным эталоном построения общества и государства. В этом отношении она показала возможный путь развития другим народам - путь модернизации общества через строительство нации как гражданской, политической общности. При этом следует подчеркнуть, что Великая Французская революция не отрицала культурных ценностей и норм. Она утвердила, что в основе бытия нации французов лежат ценности и нормы модернизированной французской культуры.

Революция в России развивалась по иному, чем Великая Французская революция, пути. Она отвергла идею нации, поднятую на знамена революции во Франции. Февраль и Октябрь обратились к вопросу о власти и проблемам социального переустройства бывшей Российской империи, не поставив вопроса о национально-политической модернизации жизни русского народа. Современный российский философ А.В. Нехаев следующим образом определяет сущностное отличие «национальной» Французской революции от «национальной» Русской: «Национальная революция, подобная Великой Французской, комплементарна эмансипирующей силе национализма, которая обычно находит выражение в той или иной партикулярной доктрине гражданского национализма. Народная же революция, подобная Великой Русской, напротив, комплементарна репрессивной силе национализма, манифестируемой различного рода эксклюзивными формами этнического национализма. Великая Французская революция приравняла народ (по крайней мере в лице третьего сословия) к нации, Великая Русская революция, напротив, растворила нарождающуюся нацию в безликих народных массах. Великая Французская революция сменила старый режим (L'ancien régime) национальным государством,
Великая Русская революция - государством партийным» [12. С. 7].

Вопрос о строительстве «русской нации» революционные партии в России не поднимали. Русский религиозный философ Н.А. Бердяев, переживший революцию в России, возлагал вину за это на революционеров. Он писал об их деятельности: «Для вас не существует России как высшей реальности, как цельного замысла Божьего, для вас существует лишь народ, не народ - нация, не живое существо, не цельный организм, существующий тысячелетие, объединяющий все поколения, а народ - крестьяне и рабочие с их преходящими материальными интересами. Во имя блага народа вы убивали Россию, убивали великую нацию с великой судьбой» [13. С. 496]. Для русского народа революция в России стала национальной катастрофой. В такой негативной ее оценке в масштабе национальной истории сходилось большинство представителей интеллектуальной элиты страны, не принадлежавших к лагерю победителей. Историк и лидер кадетов П.Н. Милюков писал о революции как о «великой национальной катастрофе», перед лицом которой оказался русский народ [14. С. 21]. Такого же мнения придерживался русский религиозный философ И.А. Ильин. Он писал: «Революция есть катастрофа в истории России, величайшее государственно-политическое и национально-духовное крушение, по сравнению с которым Смута бледнеет и меркнет» [15].

Пришедшие в результате Русской революции к власти большевики предложили оригинальный социалистический путь развития страны, который воспринимался современниками как грандиозный социальный эксперимент. Максим Горький, много сделавший для развития революционного процесса в России, был поражен жестокостью политики большевиков в отношении русского народа. В «Несвоевременных мыслях» Горький писал: «Вообразив себя Наполеонами от социализма, ленинцы рвут и мечут, довершая разрушение России - русский народ заплатит за это озерами крови». При этом «певец революции» видел в социалистическом эксперименте большевиков и национальную подоплеку, отмечая, что «Ленин “вождь” и - русский барин, не чуждый некоторых душевных свойств этого ушедшего в небытие сословия, а потому он считает себя вправе проделать с русским народом жестокий опыт, заранее обреченный на неудачу» [16. С. 83-84]. Максим Горький был только одним из многих современников революционных событий, писавших о Русской революции как о грандиозном эксперименте. Известный писатель русской эмиграции И.Ф. Наживин, наблюдавший воочию за развитием Русской революции, в своих записках о ней также писал: «Несколько лет тому назад какой-то фельетонист предложил правительству проект: вместо того, чтобы тратить бесконечные миллионы на борьбу с революцией, отдать эти колоссальные средства революционерам вместе с одной из самых богатых областей России, с тем чтобы область 
эту с помощью этих миллионов они бы сделали опытным полем революции, на котором бы и применили свои теории на практике. Если опыт их удастся, то все человечество, конечно, пойдет за ними, своими спасителями, а если не удастся, придется смириться им. В наши дни волею судеб таким опытным полем стала вся Россия с ее необъятными пространствами, с ее колоссальными богатствами, все без исключения внешние препятствия пали с легкостью прямо волшебной, твори, созидай! И сотворили: в несколько месяцев от богатого, старого и красивого дома остался только пепел да безобразно торчащие обгорелые трубы, и среди всего этого разрушения, и срама, и крови - зверообразное, страшное, безумное существо, бывший хозяин старого дома...» [17. С. 38].

В современной российской историографии взгляд на Октябрь как национальную катастрофу утвердился довольно прочно. На круглом столе, посвященном 90-летию Октября, об этом единодушно говорили большинство участников, придерживающихся различных исторических и общественно-политических взглядов. А.Н. Медушевский подчеркнул, что в широком смысле «это цивилизационная катастрофа, отказ от правового европейского пути развития, ретрадиционализация общества, как говорил П.Н. Милюков, переход его из XX в. в XVII-й, разрушение институтов гражданского общества и политической демократии, созданной Февральской революцией и всем предшествующим развитием...» [6. С. 168]. Л.Г. Протасов, сделав акцент на революционной модернизации, также охарактеризовал Октябрь как катастрофу. Историк заявил: «В целом Октябрь явился катастрофической (в научном понимании термина) формой модернизации России, варварской формой прогресса» [Там же. С. 170]. Объясняя причину катастрофы, постигшей Россию, А.Н. Боханов абсолютно верно заметил: «Наша революция отличалась от Французской, от Английской революции, потому что это была первая в мире революция, где интернационализм победил национализм, а идея классовой борьбы победила национальную идею» [Там же. С. 169]. Можно спорить о том, была в России одна революция или две, но бесспорен факт, что социалистический Октябрь определил характер развития страны, отвергнув русскую национальную идею формулировкой которой занималась значительная часть отечественной интеллигенции в начале XX в. Революция пожертвовала русскими национальными задачами во имя мессианской идеи социализма. В этой связи С.Л. Франк лаконично определил революцию как «самоубийство великого народа» [18. С. 251]. В этой связи правомерно задаться вопросом: а может ли национальное самоубийство в стране, его совершившей, носить название «Великой революции»?

Однозначно ответить на поставленный вопрос невозможно. При ответе на него необходимо иметь в виду как минимум три противоречивых обстоятельства. Во-первых, не отрицая имевшего место заговора имперских верхов против императора и активного участия иностранцев в революционных событиях, следует подчеркнуть, что это была именно народная революция, так как ее поддержали народные массы. Они приняли в ней самое активное участие. Русский народ в массе своей в ходе Февраля поддержал либералов и умеренных социалистов, не решивших оперативно основные вопросы, породившие революцию. Тогда в Октябре он пошел за радикальными социалистамибольшевиками. Либеральный историк П.М. Милюков увидел специфически русские черты в революции в России. О ее исторических корнях он писал: «Изучение русской истории приобретает в наши дни новый своеобразный интерес, ибо по социальным и культурным пластам, оказавшимся на поверхности русского переворота, внимательный наблюдатель может наглядно проследить историю нашего прошлого. То, что поражает в современных событиях постороннего зрителя, что впервые является для него разгадкой векового молчания "сфинкса", русского народа, то давно было известно социологу и исследователю русской исторической эволюции. Ленин и Троцкий для него возглавляют движение, гораздо более близкое к Пугачеву, к Разину, к Болотникову - к 18-му и 17-му векам нашей истории, чем к последним словам европейского анархо-синдикализма» [14. С. 17]. Философ Н.А. Бердяев еще в годы Гражданской войны в России указывал, что «русский коммунизм более традиционен, чем обыкновенно думают, и есть трансформация и деформация старой русской мессианской идеи» [19. С. 397]. Революция в России была русской народной революцией. Советское нациестроительство явилось следствием Русской революции, которая привела к власти в России коммунистов. Они с опорой на отдельные элементы русской культуры попытались создать новую социальную общность - советский народ. Британский русист Дж. Хоскинг признал модернизированную русскую специфику советского проекта: «Советский Союз оказался в определенном смысле по-настоящему русским. Большевизм возродил элементы уходящей в прошлое, в XVI в., и унаследованной от него системы русских мифов и символов, идею, что у России особая миссия в этом мире жить праведно и распространять “правду” (т.е. истину и справедливость), которая основывалась на эгалитаризме и на скромном образе жизни простого трудового народа» [20. С. 464].

Во-вторых, революция стала показателем кризиса традиционных основ культуры русского народа, нуждавшихся в модернизации в условиях мировой войны. Один из руководителей белого движения Юга России А.И. Деникин свой фундаментальный труд, посвященный Русской революции, назвал «Очерки русской смуты». В его начале он описывает падения религиозности народа, видя в этом показатель кризиса культуры, явившегося основной причиной революции. А.И. Деникин писал: «Религиозность русского народа, установившаяся за ним веками, к началу XX столетия несколько 
пошатнулась. Как народ-богоносец, народ вселенского душевного склада, великий в своей простоте, правде, смирении, всепрощении - народ поистине христианский терял постепенно свой облик, подпадая под власть утробных, материальных интересов, в которых сам ли научался, его ли научали видеть единственную цель и смысл жизни». В качестве иллюстративного примера генерал приводит следующий эпизод: «Мне невольно приходит на память один эпизод, весьма характерный для тогдашнего настроения военной среды. Один из полков 4-й стрелковой дивизии искусно, любовно, с большим старанием построил возле позиций походную церковь. Первые недели революции... Демагог поручик решил, что его рота размещена скверно, а храм - это предрассудок. Поставил самовольно в нем роту, а в алтаре вырыл ровик для... Я не удивляюсь, что в полку нашелся негодяй-офицер, что начальство было терроризовано и молчало. Но почему 2-3 тысячи русских православных людей, воспитанных в мистических формах культа, равнодушно отнеслись к такому осквернению и поруганию святыни?» [21. С. 64]. Ответ на поставленный генералом вопрос очевиден - народ переживал мировоззренческий кризис. Вместе с народом кризису оказалась подвержена и Русская Православная Церковь (РПЦ), веками оберегавшая национальные традиции. Накануне Русской революции, духовенство РПЦ, по наблюдениям современных исследователей, постепенно не только политизировалось, но и левело [22. С. 271]. Это означало, что даже самая консервативная часть русской интеллигенции перестала выполнять роль по сохранению традиционной культуры народа, духовно дезориентированного в условиях военных катаклизмов.

В-третьих, политическая элита России не генерировала национальной идеи. Накануне Февраля правые партии, выступавшие с национальными лозунгами русского народа, превратились, по замечанию исследователя Ю.И. Кирьянова, в «недееспособные партийные объединения, потерявшие какую-либо значимость в общественном движении» [23. С. 229]. В революционных условиях расколотая на противоборствующие политические партии либеральной и социалистической ориентации, чуждая народу элита не сориентировала его на национальную идею, а повела в политическую борьбу под социально-классовыми лозунгами. Для того, чтобы по характеру революция была национальной «Русской», она должна была поставить на повестку дня вопрос о модернизации имперского народа в русскую нацию. Но этого ее вождями не было сделано. Следует признать, что главная причина отрицания Русской революцией национальной идеи заключается в том, что со времен Петра I элита в значительной степени стала состоять из иностранцев и «инородцев», оказавшихся на государственной службе, для которых была близка идея Великой России как государства, но чужды национальные ценности и идеалы культуры русского народа. После победы Февраля в стране не нашлось политической силы, выступившей с национальными лозунгами. Боровшиеся за власть политические партии взяли на вооружение западные социальные идеологии. Выступавшие за преобразование России по западным образцам кадеты представляли либеральную альтернативу развития страны. Социалистическая альтернатива предлагала умеренный (большинство эсеров и меньшевики) и радикальный варианты (большевики и левые эсеры) развития страны. Таким образом, в 1917 г. не нашлось политической партии, способной заявить о национальных интересах русского народа, когда-то создавшего российскую государственность. А.И. Вдовин написал об исторической судьбе русского народа в XX в. правдиво и трагично: «Осмысление пути русского народа через драматический XX век приводит к убеждению, что коренная причина разрушения Российской Империи в 1917 г. и Советского Союза в 1991 г. заключается в отчуждении между государством и русским народом, в равнодушии наиболее многочисленного народа к судьбе “империи”, утратившей способность к выражению и защите его национальных интересов и ценностей» [24. С. 3]. Сто лет назад политическая элита бывшей Российской империи отвергла «русскую национальную идею», ориентируясь на решение социальных вопросов и пытаясь построить общество на основе социальных принципов. Революция сделала роковой для русской культуры выбор в пользу сначала «обрусивания» (термин П.Б. Струве), а затем и «осовечивания». В СССР коммунистами была выбрана модель построения многонациональной советской нации - советского народа. Это была социальная общность, создававшаяся в результате грандиозного по своим масштабам эксперимента по модернизации человека в условиях перехода от аграрно-индустриального к индустриальному обществу. Эта общность оказалась в значительной мере оторванной от кода русской культуры, сохраняя лишь его отдельные элементы.

События столетней давности перекликаются с современностью. В настоящее время, как и 100 лет назад, российская элита стремиться «обрусиваться», понимая необходимость национальной консолидации граждан, ставит вопрос о формировании не русской, а российской нации. В октябре 2016 г. Президент России В.В. Путин поддержал идею создания отдельного федерального закона о российской нации [25]. Об опасности «обрусивания» русских еще 100 лет назад аргументированно предупреждал известный философ и политический деятель П.Б. Струве. Накануне Русской революции он писал: «Для меня важно сейчас подчеркнуть, что ради идеала человечной, справедливой и разумной государственности - русская интеллигенция обесцвечивает себя в “российскую”. Этот космополитизм очень “государственен”, ибо “инородцев” нельзя ни физически истребить, ни упразднить как таковых, т.е. нельзя сделать "русскими”, а можно лишь восприять в единое "российское" лоно и в нем упокоить. Но позвольте мне, убежденному стороннику “государственности”, восстать против обнаруживающейся в этом случае чрезмерности 
культа государственного начала. Позвольте мне сказать, что так же, как не следует заниматься “обрусением” тех, кто не желает “русеть”, так же точно нам самим не следует себя “обрусивать”. Прошу прощения за это варварское слово, но его нужно было выдумать, ибо на самом деле интеллигенция давно “обрусивает” себя, т.е. занимается тем, что - во имя своего государственного идеала - безнужно и бесплодно прикрывает свое национальное лицо» [26. С. 221].

В юбилейный год Русской революции следует подчеркнуть, что если и ставить вопрос о нации в России, то в соответствии с ее историей и уроками Русской революции это должна быть «русская нация». Русские сумели включить в орбиту созданной ими цивилизации сотни народов, которые имели массу выгод от совместного проживания в полиэтническом и поликонфессиональном «государстве русского народа», исторически являвшимся наднациональным образованием, скрепленным русской державной идеей, русским языком и русской культурой. В дореволюционной истории России было множество русских немцев, евреев, грузин, армян и пр. - людей, не терявших связей со своей культурой и одновременно идентифицировавших себя с русской культурой. При таком подходе самый многочисленный в России народ исторически считал государство «своим», испытывал чувство национальной гордости. Распад СССР не привел к «русскому ренессансу». Однако XXI в. уже актуализировал русскую идею, дающую шанс российской государственности наращивать свое геополитическое влияние и расширять пространство за счет «русского мира». Именно об этом свидетельствуют события «русской весны», в ходе которых народ Крыма сделал выбор в пользу присоединения к России на основании истории русского народа, сделавшей легитимным выбор крымчан. Идею «русской весны» лаконично выразил известный политик, спикер парламента Новороссии Олег Царев: «Русская весна это Россия, встающая с колен. Русская весна - это проснувшаяся вера русских в себя, в свои силы. Русская весна - это Крым уже дома и Донбасс, стоящий на пороге с протянутыми к России руками» [27]. Именно русская история и культура дали право крымчанам поставить вопрос о воссоединении с исторической родиной. В контексте сказанного нельзя не согласиться с известным отечественным специалистом по истории русского народа Н.А. Нарочницкой, выступающей против оторванной от истории идеи построения нации «россиян» и поддерживающей идею развития русского гражданского движения. Исходя из исторического опыта бытия России, она обоснованно подчеркивает, что «восстановление именно нации как единого приемственно живущего организма: с общими целями, ценностями, с общим духом, миросозерцанием, с общими историческими переживаниями - вот что даст энергию, заставит опять поверить в свои силы и созидать. Сегодня нас учат тому (часто это делается косвенно или прямо), что нация - это так, совокупность индивидов с отметкой в паспорте. Однако это не так, это совершенно не так. Категории “я” и “мы” живут неслиянно и нераздельно. Принадлежность к “мы” наделяет личность “я” такими качествами, которых вообще не было у этой личности самой по себе» [28. С. 93].

Таким образом, исходя из самого значения термина «революция», Русская революция не может рассматриваться как событие небольшой временной продолжительности. Точка зрения о наличии в России с февраля по октябрь 1917 г. двух революций сформировалась под влиянием политической коньюктуры и, исходя из научного понимания термина «революция», представляется неверной. Единство Великой Русской революции как исторического процесса, включающего в себя Февраль, Октябрь и Гражданскую войну, обусловлено процессуальностью революции как исторического явления, подразумевающего этапность развития и влекущего за собой радикальные перемены в основных сфеpax общественного устройства. Утверждение идеи единства Великой Русской революции позволяет рассматривать революцию как закономерный процесс развития российской цивилизации, не навешивая на его этапы ярлыки, диктуемые политической коньюктурой, и целостно оценить это событие в масштабах мировой и национальной историй.

Завершение Гражданской войны в России, являвшейся органичной частью Русской революции, определило финал революционного процесса, установившего пребывание у власти в России коммунистов и старт реализации советского проекта, где Россия существовала в форме СССР. Основой развития Советского Союза стала идея «социальной справедливости», поднятая на знамена Русской революцией. Идея «социальной справедливости», лежащая в основе коммунистической идеологии в XX в., в результате распада СССР потерпела политическое поражение на значительной части планеты. Большинство коммунистических государств перестали быть таковыми, отказавшись от коммунистической идеологии. На первый взгляд это должно было означать развеличивание Русской революции в мировой истории. Однако в исторической перспективе это не очевидно и не предопределено. Во-первых, идею «социальной справедливости», поднятую на знамена Русской революции, продолжает проводить крупнейшая на планете цивилизация, социалистическое государство демократической диктатуры народа - Китай. Во-вторых, позиции коммунистов и социалистов в России и ряде стран современного мира в последние годы укрепляются на фоне глубокого культурного упадка Западной цивилизации, свидетельствующего о кризисе либеральных ценностей. Социализм и в настоящее время привлекателен для значительной части человечества. Поэтому величие революции в России в масштабах мировой истории по сей день остаются неоспоримым.

Оценки величия Русской революции в мировой и национальной историях не совпадают. Величие революции в России в масштабах национальной истории 
представляется далеко не таким однозначным, как в истории мировой, из-за катастрофичности революционных событий для русской культуры и русского народа. Слияние в революции в России двух противоположных начал - «русскости» и «антирусскости» - антиномично. Революция стала катастрофой, поставившей под угрозу существование традиционных ценностей и норм русской культуры и лишившей русский народ державного статуса. Историческая трагедия заключалась в том, что в ходе революции полиэтничная элита бывшей Российской империи не ставила целью революционных преобразований модернизацию жизни русского народа путем создания современной «русской нации». В отличие от Франции, где революция создала нацию французов, Русская революция отвергла проект национального гражданского строительства. От революции русский народ попытался получить осуществление своих многовековых идеалов и чаяний социальной справедливости. Они были успешно увязаны вождями революции с идеей классовой борьбы. Классовая борьба делала реализацию русской национальной идеи невозможной, поскольку национальная идея требует гражданского согласия, классового мира и социального партнерства. Однако Русская революция выдвинула мессианскую социалистическую идею мирового масштаба и, несмотря на русскую катастрофу в национальном измерении, революционное социалистическое строительство в России ментально стало глубоко русским народным проектом.

События Русской революции, определившие развитие российской цивилизации в XX столетии и серьезно повлиявшие на развитие человечества, требуют извлечения исторических уроков. Они свидетельствуют, что социалистическая идея в России имеет политическую перспективу только в сочетании с национальной идеей, способной активизировать созидательный потенциал русского народа и при этом сохранить многовековую традиционную полиэтническую и поликонфессиональную специфику России. В этой связи значение Русской революции в мировой и национальной историях зависит не от ушедшего прошлого, а от настоящего и будущего. С должной исторической дистанции значение величия революции в России в истории можно будет оценить по меньшей мере еще через сто лет, в год 200-летия Русской революции. Многое в этой оценке будет зависеть от того, смогут ли современные сторонники социализма учесть фатальную ошибку Русской революции, отвергнувшей «национальную идею» во имя идеалов «социальной справедливости».

\section{ЛИТЕРАТУРА}

1. Аксенов В.Б. Революция и насилие в воображении современников: слухи и эмоции «медового месяца» 1917 г. // Российская история. 2017 . № 2. C. $17-32$.

2. О круглом столе, посвященном столетию революции 1917 года URL: http://www.history.nsc.ru/news/krustol_1917.htm (дата обращения: 01.10.2015).

3. Бульст Н., Козеллек Р., Майер К., Фиш Й. Революция, бунт, смута, гражданская война // Словарь основных исторических понятий : избранные ст. : в 2 т. / сост. Ю. Зарецкий, К. Левинсон. М. : Новое литературное обозрение, 2014. Т. 1. 736 с.

4. Троцкий Л.Д. История русской революции : в 2 т. М. : ТЕРРА ; Республика, 1997. Т. 1 : Февральская революция. 464 с.

5. Керсновский А.А. История русской армии : в 4 т. М. : Голос, 1994. Т. 4. 368 с.

6. Российские революции: 90 лет спустя : круглые столы в институте Российской истории РАН // Отечественная история. 2008 . № 6. С. 167-211.

7. Послание Президента России Федеральному Собранию 1 декабря 2016 года URL: http://kremlin.ru/events/president/news/53379 (дата обращения: 01.10.2015).

8. Шепелева В.Б. Историки «советского проекта» в контексте постнеклассической познавательной парадигмы // Северо-Восточный гуманитарный вестник. 2016. № 1 (14). С. 36-42.

9. Фельдман М.А. Социалистическая мысль в преддверии столетия Октября // Общественные науки и современность. 2016. № 1. С. 170-175.

10. Тойнби А. Цивилизация перед судом истории. М. : Айрис-пресс, 2003. 592 с.

11. Гринфельд Л. Национализм. Пять путей к современности. М. : ПЕР СЭ, 2012. 528 с.

12. Нехаев А.В. Революция 1917 года в России: поражение «нации» или победа «народа»? // Омский научный вестник. Сер. Общество. История. Современность. 2017. № 2. С. 6-8.

13. Бердяев Н.А. Философия неравенства // Судьба России : сочинения. М. : ЭКСМО-Пресс ; Харьков : Фолио, 1998.736 с.

14. Милюков П.Н. История второй русской революции. М. : Рос. полит. энциклопедия (РОССПЭН), 2001. 767 с.

15. Ильин И.А. Русская революция как катастрофа, преступление и безумие URL: https://history.wikireading.ru/342788 (дата обращения: $01.10 .2015)$

16. Горький М. Несвоевременные мысли и рассуждения о революции и культуре (1917-1918 гг.). М. : МО Союза журналистов СССР ; Ассоциация «Ротация» при участии МСП «Интерконтракт», 1990. 192 с.

17. Наживин И.Ф. Записки о революции / вступ. ст. А.В. Посадского. М. : Кучково поле, 2016. 384 с.

18. Франк С.Л. De profundis // Из глубины : сб. статей о русской революции. М. : Изд-во Моск. ун-та, 1990. С. $251-269$.

19. Бердяев Н.А. Истоки и смысл русского коммунизма // Избранные труды. М. : Рос. полит. энциклопедия (РОССПЭН), 2001.767 с.

20. Хоскинг Д. Правители и жертвы. Русские в Советском Союзе. М. : Новое литературное обозрение, 2012.544 с.

21. Деникин А.И. Очерки Русской Смуты / предисл. А.С. Пученкова. М. : АЙРИС-пресс, 2017. Т. 1: Крушение власти и армии (февраль-сентябрь 1917). $672 \mathrm{c}$

22. Булдаков В.П., Леонтьева Т.Г. Война, породившая революцию. М. : Новый хронограф, 2015.720 с.

23. Кирьянов Ю.И. Численность и состав правых партий в России в 1914-1917 гг. // Россия и Первая мировая война : (материалы междунар. науч. коллоквиума). СПб. : Дмитрий Буланин, 1999. С. 216-229.

24. Вдовин А.И. Русские в ХХ веке. М.: ОЛМА-ПРЕСС, 2004. 448 с.

25. Путин подал национальную идею. URL: https://www.gazeta.ru/politics/2016/10/31_a_10295957.shtml (дата обращения: 01.10.2015).

26. Струве П.Б. Интеллигенция и национальное лицо // Нация и империя в русской мысли начала ХХ века. М. : СКИМЕНЪ ; ПРЕНСА, 2004.352 с.

27. Царев О. Что такое «Русская Весна»? URL: http://rusvesna.su/recent_opinions/1457031842 (дата обращения: 01.10.2015).

28. Нарочницкая Н.А. Сосредоточение России. Битва за русский мир. М. : Изборский клуб ; Книжный мир, 2015.320 с. 
Keywords: Revolution in Russia; Russian Revolution; February Revolution; October Revolution; socialism.

The article is devoted to the analysis of changes in significance evaluations of the Russian Revolution on the scale of world and national histories from 20th century to beginning of the 21 st century. The main article's problem is the question of determining the grounds that give historians right to assert the greatness of the Russian Revolution into the frame of world and national histories. To solve the problem posed, the author turned to the discussion in historiography about the existence of two or one revolution in the Russian history in 1917. On the basis of the history of concepts toolkit the article supports the point of view about existence of a single historical event, and the February and the October were its most important stages. The question of Russian Revolution greatness into the frame of world and Russian histories is solved on the basis of the principle of interdisciplinary synthesis. The author relies on a wide range of works of historians and philosophers in his conclusions. Memoirs of contemporaries about events of the Russian revolution are used as a main source for the article. The problem of criteria determining for greatness of the Russian Revolution into the frame of world and national histories is solved separately in the article. A comparative analysis of the Great French and Great Russian Revolutions is used to solve it. As a result, the author came to the following conclusions. Firstly, the greatness of the Russian Revolution into the frame of world history is due to the influence of revolutionary events on the mankind development, and it is beyond doubt. The Russian Revolution offered mankind a groundbreaking idea of social justice expressed in communist ideology as the basis for development of society at the time. The communist ideology in Russia had specifically Russian features. The main of these was the messianism. The Russian Revolution had spurred throughout the 20th century many people to see the communism as an alternative to Western liberalism. Secondly, the Russian Revolution developed in a different way than the Great French Revolution. It rejected the idea of the nation raised on the banner of the revolution in France. The revolution in Russia became a national catastrophe for the Russian people on the national history scale. Thirdly, the Russian Revolution significance into the frame of world and national histories depends not on the past but on the present and the future. Much in these evaluations will depend on whether modern supporters of socialism can take into account the fatal error of the Russian Revolution that rejected the "national idea" in the name of the ideals of the "social justice".

\section{REFERENCES}

1. Aksenov, V.B. (2017) Revolyutsiya i nasilie v voobrazhenii sovremennikov: slukhi i emotsii "medovogo mesyatsa" 1917 g. [Revolution and violence in the imagination of contemporaries: rumors and emotions of the "honeymoon" of 1917]. Rossiyskaya istoriya. 2. pp. 17-32.

2. Institute of History, SB RAS. (2017) O kruglom stole, posvyashchennom stoletiyu revolyutsii 1917 goda [About the round table devoted to the centenary of the revolution of 1917]. [Online] Available from: http://www.history.nsc.ru/news/krustol_1917.htm. (Accessed: 1st October 2017)

3. Bulst, N., Kosellek, R., Mayer, C. \& Fish, J. (2014) Revolyutsiya, bunt, smuta, grazhdanskaya voyna [Revolution, rebellion, unrest, civil war]. In: Zaretskiy, Yu., Levinson, K. (eds) Slovar' osnovnykh istoricheskikh ponyatiy: Izbrannye stat'i v 2-kh t. [Dictionary of Basic Historical Concepts: Selected Articles in 2 vols]. Vol. 1. Moscow: Novoe literaturnoe obozrenie.

4. Trotskiy, L.D. (1997) Istoriya russkoy revolyutsii: V 2 t. [The History of the Russian Revolution: In 2 vols]. Vol. 1. Moscow: TERRA; Respublika.

5. Kersnovskiy, A.A. (1994) Istoriya russkoy armii v 4-kh tomakh [History of the Russian army in 4 vols]. Vol. 4 . Moscow: Golos.

6. Institute of Russian History, RAS. (2008) Rossiyskie revolyutsii: 90 let spustya. Kruglye stoly v institute Rossiyskoy istorii RAN [Russian revolutions: 90 years later. Round tables at the Institute of Russian History of the Russian Academy of Sciences]. Otechestvennaya istoriya. 6. pp. 167-211.

7. President of the Russian Federation. (2016) Poslanie Prezidenta Rossii Federal'nomu Sobraniyu 1 dekabrya 2016 goda [Address of the President of Russia to the Federal Assembly on December 1, 2016]. [Online] Available from: http://kremlin.ru/events/president/news/53379. (Accessed: 1st October2017).

8. Shepeleva, V.B. (2016 The origins of "the Soviet project" in the context of post non-classical cognitive paradigm. Severo-Vostochnyy gumanitarnyy vestnik - North Eastern Journal of the Humanities. 1(14). pp. 36-42. (In Russian).

9. Feldman, M.A. (2016) Socialist Thought in Anticipation of the Centennial of the October. Obshchestvennye nauki i sovremennost' - Social Sciences and Contemporary World. 1. pp. 170-175. (In Russian).

10. Toynbee, A. (2003) Tsivilizatsiya pered sudom istorii [Civilization on Trial]. Translated from English by E. Zharkov, A. Kharitonovich, I. Kiseleva. Moscow: Ayris-press.

11. Greenfeld, L. (2012) Natsionalizm. Pyat' putey k sovremennosti [Nationalism: Five Roads to Modernity]. Translated from English by T. Gringolts, M. Virozub. Moscow: PER SE.

12. Nekhaev, A.V. (2017) Revolyutsiya 1917 goda v Rossii: porazhenie "natsii" ili pobeda "naroda"? [The revolution of 1917 in Russia: the defeat of the "nation" or the victory of the "people"?]. Omskiy nauchnyy vestnik. Seriya "Obshchestvo. Istoriya. Sovremennost"”- Omsk Scientific Bulletin. Society. History. Modernity. 2. pp. 6-8.

13. Berdyaev, N.A. (1998) Sud'ba Rossii: Sochineniya [The Fate of Russia: Works]. Moscow: EKSMO-Press; Kharkov: Folio.

14. Milyukov, P.N. (2001) Istoriya vtoroy russkoy revolyutsii [The History of the Second Russian Revolution]. Moscow: ROSSPEN.

15. Ilin, I.A. (n.d.) Russkaya revolyutsiya kak katastrofa, prestuplenie i bezumie [Russian revolution as a catastrophe, crime and madness]. [Online] Available from: https://history. wikireading.ru/342788. (Accessed: 1st October 2017).

16. Gorky, M. (1990) Nesvoevremennye mysli i rassuzhdeniya o revolyutsii i kul'ture (1917-1918 gg.) [Untimely thoughts and arguments about revolution and culture (1917-1918)]. Moscow: Union of Journalists of the USSR.

17. Nazhivin, I.F. (2016) Zapiski o revolyutsii [Notes on the Revolution]. Moscow: Kuchkovo pole.

18. Frank, S.L. (1990) De profundis. In: Askkoldov, S.A. et al. Iz glubiny: Sbornik statey o russkoy revolyutsii [From the depths: Collection of articles about the Russian revolution]. Moscow: Moscow State University. pp. 251-269.

19. Berdyaev, N.A. (2001) Izbrannye trudy [Selected Works]. Moscow: ROSSPEN.

20. Hosking, D. (2012) Praviteli i zhertvy. Russkie v Sovetskom Soyuze [Rulers and Victims. The Russians in the Soviet Union]. Translated from English by V. Artyomov. Moscow: Novoe literaturnoe obozrenie.

21. Denikin, A.I. (2017) Ocherki Russkoy Smuty [Essays on the Russian Troubles]. Vol. 1. Moscow: AYRIS-press.

22. Buldakov, V.P. \& Leonteva, T.G. (2015) Voyna, porodivshaya revolyutsiyu [The war that gave rise to the revolution]. Moscow: Novyy khronograf.

23. Kiryanov, Yu.I. (1999) Chislennost' i sostav pravykh partiy v Rossii v 1914-1917 gg. [The number and composition of right-wing parties in Russia in 1914-1917]. In: Smirnov, N.N. (ed.) Rossiya i Pervaya mirovaya voyna [Russia and] WWI. St. Peterburg: Dmitriy Bulanin. pp. $216-229$.

24. Vdovin, A.I. (2004) Russkie v XX veke [The Russians in the Twentieth Century]. Moscow: OLMA-PRESS.

25. Vinokurov, A. (2016) Putin podal natsional'nuyu ideyu [Putin submitted a national idea]. [Online] Available from: https://www.gazeta.ru/politics/2016/10/31_a_10295957.shtml. (Accessed: 1st October 2017).

26. Struve, P.B. (2004) Intelligentsiya i natsional'noe litso [Intellectuals and the national face]. In: Sergeev, S.M. et al. Natsiya $i$ imperiya $v$ russkoy mysli nachala XX veka [Nation and Empire in Russian Thought of the early 20th Century]. Moscow: SKIMEN; PRENSA.

27. Tsarev, O. (2016) Chto takoe "Russkaya Vesna"? [What is the "Russian Spring"?]. [Online] Available from: http://rusvesna.su/recent_opinions/1457031842. (Accessed: 1st October 2017)

28. Narochnitskaya, N.A. (2015) Sosredotochenie Rossii. Bitva za russkiy mir [The concentration of Russia. Battle for the Russian world]. Moscow: Izborskiy klub, Knizhnyy mir. 